energy and industrial technology, and is to some extent an inheritance from Professor Homi Bhabha, who was killed in an aeroplane crash on Mont Blanc in January 1966. Bhabha was a great man and a great scientist, described by Yehudi Menuhin as "the twentieth-century Leonardo"; but having heard him lecture on the needs of science in developing countries, I cannot believe that in this particular respect his ideas were right. Attractive as may be the switching of surplus agricultural workers into urban industries and of scientific excellence in atomic physics, nearly all the people of India will continue to depend for their eivilization on biological productivity.

There is almost no mention of biology in Ashok Parthasarathi's article. But Cinderella will some day find that the shoe fits.

$$
\begin{aligned}
& \text { Yours faithfully, } \\
& \text { E. B. WorthINGTON }
\end{aligned}
$$

International Biological Programme,

Central Office,

7 Marylebone Road,

London NWl.

\section{Laboratory at Porton Down}

SIR,-As one who was privileged to be present at the recent opening of the new Physics Laboratory at the Chemical Defence Experimental Establishment by Mr J. Morris, Minister of Defence for Equipment, I feel that the brief note in your issue of March 29 (Nature, 221, 1187; 1969) does an injustice to those responsible for the design of this fine building. The perspective of the photograph, reproduced in black and white, does not show to advantage the elegant proportions of the building nor can the picture reveal the striking but pleasing contrast between the colour of the brickwork with that of the panels under the windows. Where there is a conflict between architectural and functional requirements, as in most laboratory buildings, some sacrifice of aesthetic appeal is bound to be made, but in this case the Ministry of Public Building and Works has been remarkably successful in producing a design which is far superior to the boxlike structures so often inflicted on us in the present age.

If there are detractors of research in chemical warfare who might be foolish enough to rejoice, as you suggest, at a lack of architectural distinction, then, by the same token, they would gnash their teeth in rage at the interior of the building with its attractive decor and finely equipped suites of special purpose laboratories. The taxpayer has been well served and the staff has reaped a just reward after nearly five decades of working under adverse conditions in primitive factory-type buildings. Here is a building which will delight the hearts of physicists and will provide an environment attractive to young men and women who are prepared to dedicate themselves to dofence science while, at the same time, being given almost unlimited opportunities to make worthwhile contributions to aerosol physies, industrial hygiene and the like, for the benefit of mankind at large. Yours faithfully,

Milford Hall

H. L. Green

Castle Street,

Salisbury, Wiltshire.

\section{University News}

Mr R. A. G. Savigear, University of Sheffield, has been appointed to a second professorship in the Department of Geography at the University of Reading.

Dr T. G. Taylor, Poultry Research Centre, Edinburgh, has been appointed to the Rank chair of applied nutrition at the University of Southampton.
Dr J. G. Taylor, Queen Mary College, London, has been appointed to a chair of theoretical physies at the University of Southampton.

Dr A. H. Uhl has been named the Edward Kremers professor of pharmacy at the University of Wisconsin. Dr R. G. Smith, University of Keele, has been appointed professor of mathematics of the Open University. Mr D. J. Simpson, University of Glasgow, will become librarian and director of media resources of the Open University.

Professor W. A. C. Stewart, vice-chancellor of the University of Keele, has been appointed chairman of the Universities Council for Adult Education.

\section{Appointments}

Dr Edward Chin, associate professor, Texas $\mathbf{A}$ and $\mathbf{M}$ University, Marine Laboratory, Galveston, Texas, has been appointed program director for biological oceanography, Environmental and Systematic Biology Section, Division of Biological and Medical Sciences, at the National Science Foundation. Dr Philip L. Johnson, formerly associate professor, School of Forest Resources and Institute of Ecology, University of Georgia, has been appointed program director for environmental biology in the same section at the National Science Foundation.

\section{Announcements}

Dr D. A. Hilding, Yale University, has been presented with the Harris P. Mosher Award of the Triological Society for his research on the development of the cochlea.

Dr G. E. Adams, Mount Vernon Hospital, has been awarded the Radiation Research Society's Research Award for 1969 in recognition of his contributions to radiation research.

Dr C. M. Williams, Harvard University, will receive the 1969 Howard Taylor Ricketts Award from the University of Chicago in recognition of his discovery of juvenile hormones in insects.

The Patron's Medal of the Royal Geographical Society has been awarded to Rear-Admiral R. N. M. Panzarini, formerly director of the Argentine Antarctic Institute, for services to Antarctic Exploration and Research. 'The society's Founder's Medal has been awarded to Dr R. Thorsteinsson and Dr E. T. Tozer, Department of Mines and Technical Surveys, Canada, in recognition of their contributions to exploration and economic development in the Canadian Arctic. The Victoria Medal has been awarded to Marcel Aurousseau, former secretary to the permanent committee on geographical names; the Murchison Grant to Professor J. T. Coppock, University of Edinburgh, for agricultural studies; the Back Grant to Mr A. J. Lee, Fisheries Laboratory, Lowestoft, for contributions to oceanography; the Cuthbert Peek Grant to Dr E. C. F. Bird, University of Melbourne, for coastal studies; the Gill Memorial to Dr R. M. Prothero, University of Liverpool, for population studies; the Ness Award to Mr R. G. Clarke, Hovercraft Commander, Geographical Magazine Amazonas Expedition, and the Cherry Kear ton Medal and Award to Alan and Joan Root, for contributions to natural history and nature photography.

ERRATUM. In the article "Will ELDO Last ?" (Nature, 221,1183 ; 1969) it was incorrectly stated that the chairman at the first meeting of the newly created Committee of High Officials was Professor $\mathrm{H}$. Bondi. In fact Professor Bondi took the chair (representing the chairman of the European Space Conference, Minister Dr G. Stoltenberg) while the Committee elected as its chairman Professor G. Puppi. 


\section{International Meetings}

April 22-30, International Chemical and Petroleum Engineering Exhibition, London (F. W. Bridges and Sons, Ltd, Commonwealth House, New Oxford Street, London WC1).

May 10, Basic Genetics-L. J. Stadler Memorial Symposium, Missouri (Dr G. Kimber, Department of Genetics, University of Missouri, Columbia, Missouri 65201, USA). May 26-28, 52nd Chemical Conference of the Chemical Institute of Canada, Montreal (Chemical Institute of Canada, 151 Slater Street, Ottawa 4, Ontario, Canada).

May 26-28, Diversity and Stability in Ecological Systems, New York (Symposium Committee, Brookhaven National Laboratory, Associated Universities Inc., Upton, LI, NY 11973, USA).

June 9-27, Marine Geochemistry, Rehovot (Weizmann Institute of Science, London Foundation Office, Rex House, 4/12 Regent Street, London SW1).

June 23-July 6, Chemistry of Solid/Liquid Interfaces, Cavtat (Professor B. Težak, Institute "Ruder Bošković", POB 171, Zagreb, Yugoslavia).

July 10, Measurement and Mathematical Techniques in Combustion/Heat-Transfer Systems, Leatherhead (Mr G. G. Thurlow, Director B, BCURA Industrial Laboratories, Randalls Road, Leatherhead, Surrey, UK). July 13-16, Physiology and Biochemistry of Muscle as a Food, Wisconsin (Mr E. J. Briskey, Muscle Biology Laboratory, College of Agricultural and Life Sciences, University of Wisconsin, Madison, Wisconsin 53706, USA). July 28-31, Computational Physics, Culham (Meetings Officer, The Institute of Physics and the Physical Society, 47 Belgrave Square, London SW1).

August 18-22, Marine Biomedicinals, Oregon (Dr P. Catalfomo, School of Pharmacy, Oregon State University, Corvallis, Oregon 97331, USA).

August 24-29, Gasdynamics of Explosions and Reactive Systems, Novosibirsk, USSR (International Academy of Astronauts of the International Astronautical Federation, 250 Rue Saint-Jacques, Paris 5, France).

August 25-29, IXth International Embryological Conference, Moscow (Professor A. S. G. Curtis, Department of Cell Biology, The University, Glasgow W2, UK).

September 1-5, Hormones and the Environment, Sheffield (Professor J. G. Phillips, Department of Zoology, University of Hull, or Dr G. K. Benson, Department of Veterinary Anatomy, University of Liverpool).

September 3-5, Product Development and Manufacturing Technology, Glasgow (Mr R. J. Brown, Information Officer, University of Strathclyde, George Street, Glasgow C1).

\section{Sabbatical Itinerants}

In the hope of providing some practical assistance in the good cause of mobility between laboratories, Nature advertises the needs for housing of families about to take up periods of sabbatical leave. To begin with, no charge will be made for advertisements like this. It is hoped that a period of experiment will show what form these advertisements could most usefully take and whether they are effective.

Wanted: Furnished, 3 or 4 bedroom house in London, convenient for University College, for one year beginning September 1, 1969. Please contact Dr Martin J. Kushmerick, Room B1-09, Building 2, National Institutes of Health, Bethesda, Maryland 20014, USA.

\section{BRITISH DIARY}

Monday, April 28

SOCIETY OF CHEMTCAL INDUSTRY, FOOD GROUP (in the Congress Theatre, Eastbourne), at 2.30 p.m.-Meeting on "The Influence of Food Technology on the Changing Patterns in the Catering Industry".

Institution of EleCTrical EnaIneERs (at Savoy Place, London, WC2), at 5.30 p.m.-Mr W. Kemp: "Educational Television".

\section{Tuesday, April 29}

Institution of Electrioal Engineers (at Savoy Place, London, WC2)Colloquium on "Distributed Parameter Systems".

CIBA FOUNDATION (at the Royal Institute of British Architects, 66 Portland Place, London, W1), at 5 p.m.--Professor Giuseppe Moruzzi (University of Pisa): "Sleep and Instinctive Behaviour" (21st (annual) Ciba Foundation Lecture).

SOcIETx of ENGINEERS (at Hanover Grand Film Theatre, 6 Hanover Street, London, W1), at 5.15 p.m. - Sir Christopher Cockerell, CBE, FRS: "Developments in Hovercraft"; Film-"The Last Great Journey on Earth".

Institution of Eleotrioar ENGineers (at Savoy Place, London, WC2), at 5.30 p.m.-Dr I. R. Smith and Mr P. A. Nisar: "A Brushless Self-excited Three-phase Synchronous Machine".

Institution of Mbchanical Engineers, Automatic ConTrol Group (joint meeting with the Institution of Electrical Engineers, at 1 Birdcage Walk, London, SW1), at 6 p.m.-Discussion meeting on "Systems Approach as a Basis for Engineering Education".

\section{Wednesday, April 30}

British Postgraduate Medical Federation, University OF LONDON (at the Institute of Child Health, 30 Guilford Street, London, WC1), at 5.30 p.m.-Dr J. G. Humble: "Leukaemias" (last of three lectures on "The Scientific Basis of Dentistry")

INSTITUTION OF ELECTRICAI ENGINRERS (at Savoy Place, London, WC2), at 5.30 p.m.-Discussion meeting on "Transistor Microwave Power Amplifiers".

INSTIYUTION OF ELIBCTRICAI FNGINEERS (at Savoy Place, London, WC2), at 5.30 p.m.-Mr G. H. Hickling, Mr A. I. Winder: "Surge Transfer through Transformer Generator Units"; Mr F. L. White: "Surge Transference Characteristics of Generator Transformer Installations".

SOCIETy FOR ANalytroal Chemistry, Migrochemicar Methods Grodp (at "The Feathers", Tudor Street, London, EC4), at 6.30 p.m.-Discussion meeting on "The Use of Instruments in the Analysis of Organic Materials" introduced by $\mathrm{Mr}$ A. G. Jones.

Society of Chrmical INDUSTry, OILS AND Fats Group (at 14 Belgrave Square, London, SW 1), at 6.30 p.m.-Dr B. J. F. Hudson: "The Changing Scene in Lipid Research".

\section{Thursday, May}

RoYal SociepY (at 6 Carlton House Terrace, London, SW1), at 4.30 p.m.Dr F. Sanger, FRS: "Sequences in Nucleic Acids".

UNIVERSITY COLLEGE LONDON (in the Chemistry Theatre, Gower Street London, WC1), at 5.30 p.m.-Dr C. A. Vernon: "Bee Venom" (Inaugural Lecture).

INSTITUTE OF REFRIGERATION (at the National College for Heating, Ventilating, Refrigeration and Fan Engineers, Southwark Bridge Road, London, SE1), at 6 p.m.-Dr M. E. Darlington: "The Use of Liquid Nitrogen in the Field of Refrigeration".

Soctety of Chemical Industry, Miorobiology Group (at the Constitutional Club, 86 St, James's Street, London, SW1), at 6 p.m.-Annual General Meeting, followed by discussion meeting on "The Proper Aims of the Microbiology Group".

Sochety OF Cosmetic Chemists of Great Britain (at the Royal Society of Arts, John Adam Street, London, WC2), at 7.30 p.m.-Mr Leonar Matchan: "An Industrialist Looks at the Cosmetic Industry" (Medal Lecture).

\section{Friday, May 2}

Royar Instrtumion, Photochemistry Disoussion Group (at 21 Albemarle Street, London, W1), at 1 p.m.-Dr J. F. McKellar: "Photochemica Problems in the Dyestuff Industry".

Royat Astronomidal Societr (at Burlington House, Piccadilly, London, W1), at 3 p.m. - Geophysical Discussion on "Anisotropy in the Upper Mantle". Chairman: Dr H. I. S. Thirlaway.

INSTITUTION OF ELECTRONIC AND RADIO ENGINEERS, JOINT IEE/IERP COMPUTRR GROUPS (at the Institution of Flectrical Engineers, Savoy Place Ton w

\section{Monday, May 5}

Instrutute of Physios and the Physical Sociexy (at the Institution of Electrical Engineers, Savoy Place, London, WC2)-Conference on "Organization and Management of Research and Development".

Institution OF FLECTRICAL ENGINEERs (at Savoy Place, London, WC2), at 5.30 p.m.-Mr S. S. D. Jones: "VLF Navigation".

SoCIETy of Chemidal IndUstry, FINE CHeMroals Group (at 14 Belgrave Square, London, SW1), at 6.30 p.m.-Dr R. E. Bowman: "Profadol-a New Potent Analgesic". 